P-ISSN 2580 - 7781

E-ISSN 2615 - 3238

\title{
RESPON PEGAWAI TERHADAP GAYA KEPEMIMPINAN DAN LINGKUNGAN KERJA DI UNIVERSITAS ABDURACHMAN SALEH SITUBONDO
}

\section{EMPLOYEE RESPONSE TO LEADERSHIP STYLES AND WORK ENVIRONMENT AT ABDURACHMAN UNIVERSITY SALEH SITUBONDO}

\author{
Lusiana Tulhusnah ${ }^{1)}$ Rasidi $^{2)}$ \\ ${ }^{1,2}$ Fakultas Ekonomi, Universitas Abdurachman Saleh \\ Email : ${ }^{1}$ lusianatulhusnah445@gmail.com
}

\begin{abstract}
ABSTRAK
Sumber daya manusia merupakan faktor utama dalam keberhasilan pada suatu lembaga, maka dari itu pegawai perlu mendapatkan kenyamanan dalam bekerja. Gaya kepemimpinan dan lingkungan kerja menjadi faktor kenyaman mereka dalam melaksanakan pekerjaanya. Penelitian ini bertujuan untuk menganalisa respon pegawai Unars terhadap gaya kepemimpinan dan lingkungan kerja yang mereka hadapi pada saat melaksanakan aktivitas di tempat kerja. Sampel ditentukan dengan menggunakan teknik sampel jenuh sebanyak 66 pegawai Unars pada bulan Mei 2020. Teknik analisis data yang digunakan pada penelitian ini adalah analisis deskriptif menggunakan index kategori. Hasil penelitian menunjukkan $65,57 \%$ puas dengan gaya kepemimpinan yang mereka rasakan dan 73,39\% puas dengan lingkungan kerja yang ada di Unars Situbondo.

Kata Kunci: Pegawai, Gaya Kepemimpinan, Lingkungan Kerja, Unars
\end{abstract}

\section{ABSTRACT}

Human resources are the main factor in the success of an institution, therefore employees need to get comfortable at work. Their leadership style and work environment are a factor in their comfort in carrying out their work. This study aims to analyze the responses of Unars employees to the leadership style and work environment they face when carrying out activities in the workplace. The sample was determined using a saturated sample technique of 66 Unars employees in May 2020. The data analysis technique used in this study was descriptive analysis using a category index. The results showed that $65.57 \%$ were satisfied with the leadership style they felt and $73.39 \%$ were satisfied with the work environment in Unars Situbondo.

Keywords: Employees, Leadership Style, Work Environment, Unars

\section{PENDAHULUAN}

Kemajuan suatu organisasi tentunya didukung oleh orang-orang yang ada dalam organisasi atau instansi pemerintah tersebut khususnya pemimpin dan pegawai yang memiliki andil dalam menjalankan suatu organisasi atau instansi pemerintah. Suatu organisasi atau instansi pasti memiliki pemimpin, seorang pemimpin membutuhkan pegawai atau bawahan yang membantu dalam segala pekerjaannya dalam suatu organisasi atau instansi pemerintah yang dipimpinnya. Umumnya kepemimpinan yang efektif sangat dipengaruhi oleh kepribadian pemimpin, setiap pemimpin perlu memiliki aspek-aspek kepribadian yang dapat 
P-ISSN 2580 - 7781

E-ISSN 2615 - 3238

menunjang usahanya dalam mewujudkan hubungan manusia yang efektif dengan anggota organisasinya. Pemimpin yang sukses adalah apabila pemimpin tersebut mampu menjadi pencipta dan pendorong bagi bawahannya dengan memberikan motivasi, menciptakan suasana kerja, dan budaya kerja dengan gaya kepemimpinan yang dimiliki sehingga dapat memacu pertumbuhan dan perkembangan kinerja pegawainya. Menurut Nawawi (2006:115) gaya kepemimpinan adalah perilaku atau cara yang dipilih dan dipergunakan pemimpin dalam dalam mempengaruhi pikiran, perasaan, sikap, dan perilaku para anggota organisasi bawahannya.

Faktor selain gaya kepemimpinan adalah lingkungan kerja. Menurut Windura, Satriawan dan Silalahi (2017) lingkungan kerja merupakan segala sesuatu yang ada di sekitar para pekerja dan yang dapat mempengaruhi dirinya dalam menjalankan tugas yang diemban atau yang menjadi tanggung jawabnya. Untuk meningkatkan produktivitasnya maka lingkungan kerja sangat mempengaruhi kinerja, karena lingkungan kerja yang baik akan menciptakan kemudahan pelaksanaan tugas. Lingkungan kerja ini sendiri terdiri dari lingkungan kerja fisik dan non fisik yang melekat dengan karyawan sehingga tidak dapat dipisahkan dari usaha pengembangan bawahan.

Lingkungan kerja merupakan salah satu faktor yang harus diperhatikan karena berkaitan erat dengan tinggi rendahnya semangat kerja para pegawai. Jika lingkungan kerja baik maka akan dapat memicu semangat kerja yang tinggi, pada akhirnya dapat meningkatkan kinerja pegawai. Lingkungan kerja terdiri dari: (a) Lingkungan Eksternal, (b) Lingkungan Internal, Griffin (2004). Adapun menurut Sedarmayati (2009) Lingkungan kerja adalah keseluruhan alat perkakas dan bahan yang dihadapi, lingkungan sekitarnya di mana seseorang bekerja, metode kerjanya, serta pengaturan kerjanya baik sebagai perseorangan maupun sebagai kelompok.

Gaya kepemimpinan dan lingkungan kerja tidak hanya berpengaruh pada instansi pemerintah saja namun juga swasta seperti Universitas. Universitas merupakan pusat pelayanan tri dharma perguruan tinggi yang dekat dengan masyarakat. Pegawai pada Universitas swasta adalah orang yang memenuhi syarat 
P-ISSN 2580 - 7781

E-ISSN 2615 - 3238

yang ditentukan, diangkat oleh yayasan untuk melaksanakan tugas yang telah dibebankan. Pegawai Universitas mempunyai peran yang sangat menentukan keberhasilan dalam meraih tujuan, dan merupakan kunci dalam menentukan keberhasilan lembaga dalam melaksanakan kewenangan, maka kinerja pegawai harus dinilai dan ditingkatkan secara berkesinambungan.

Berdasarkan observasi awal diketahui bahwa gaya kepemimpinan dan lingkungan kerja yang diterapkan Universitas Abdurachman Saleh Stubondo (UNARS) mampu meningkatkan kinerja yang baik dalam organisasi. Atas dasar inilah penulis tertarik untuk menganalisa penelitian respon pegawai UNARS terhadap gaya kepemimpinan dan lingkungan kerja yang mereka hadapi pada saat melaksanakan aktivitas di tempat kerja.

\section{METODE PENELITIAN}

Metode penelitian yang digunakan pada penelitian ini adalah metode penelitian deskriptif. Penelitian ini menggambarkan kondisi gaya kepemimpinan dan lingkungan kerja di tempat penelitian. Populasi pada penelitian ini adalah seluruh pegawai Universitas Abdurachman Saleh Situbondo dengan jumlah 66 orang. Jumlah sampel yang digunakan pada penelitian ini berjumlah 66 orang, dimana seluruh populasi dijadikan sebagai sampel penelitian dengan menggunakan metode sampel jenuh. Data yang digunakan pada penelitian ini adalah data primer, yaitu data yang diperoleh langsung oleh peneliti dari obyek penelitian melalui penyebaran angket pada bulan Mei 2020. Teknik analisis data yang digunakan pada penelitian ini adalah analisis deskriptif menggunakan index kategori. Sebelum menentukan index kategori, terlebih dahulu menentukan interval pada setiap indikator.

Interval Presentase $=\frac{100 \%}{\text { Kelas Interval }}$

Interval Presentase $=\frac{100 \%}{5}=20$

Maka tabel kelas intervalnya adalah sebagai berikut.

$0 \%-19,99 \%=$ Sangat Tidak Puas

$20 \%-39,99 \%=$ Tidak Puas

$40 \%-59,99 \%=$ Cukup Puas 
P-ISSN 2580 - 7781

E-ISSN 2615 - 3238

$$
\begin{array}{ll}
60 \%-79,99 \% & =\text { Puas } \\
80 \%-100 \% & =\text { Sangat Puas }
\end{array}
$$

Index kategori digunakan untuk menentukan tingkat kategori rendah ataupun tinggi respon pegawai. Rumus index kategori dapat diuraikan sebagai berikut:

Index Kategori \% = Total Skor / (Y.I) x 100\%

Keterangan:

Total Skor = Jumlah perolehan skor pada setiap indikator

$\mathrm{Y}=$ Jumlah skor tertinggi skala likert $\mathrm{x}$ jumlah responden

I $=$ Jumlah pernyataan dalam setiap indikator

\section{HASIL PENELITIAN DAN PEMBAHASAN}

\section{Gambaran Distribusi Jawaban Responden}

Distribusi hasil jawaban responden yang diperoleh dari hasil penyebaran kuesioner pada karyawan Universitas Abdurachman Saleh Situbondo adalah sebagai berikut:

a. Gaya Kepemimpinan

Pada variabel gaya kepemimpinan terdapat 2 pernyataan yang mempersentasikan indikator-indikator yang terkait dengan variabel gaya kepemimpinan, berikut jawaban yang diberikan oleh responden :

\begin{tabular}{|c|c|c|c|c|c|c|c|}
\hline No & Pernyataan & STP & $\mathbf{T P}$ & $\mathbf{N}$ & $\mathbf{P}$ & SP & Skor \\
\hline 1 & $\begin{array}{l}\text { Pemimpin } \\
\text { melibatkan } \\
\text { partisipasi } \\
\text { bawahan dalam } \\
\text { setiap kegiatan } \\
\text { dengan memberi } \\
\text { dukungan tinggi } \\
\text { dan sedikit } \\
\text { pengarahan. }\end{array}$ & $0 \%$ & $1,5 \%$ & $24,2 \%$ & $51,5 \%$ & $22,7 \%$ & $100 \%$ \\
\hline 2 & $\begin{array}{l}\text { Pimpinan senang } \\
\text { menerima saran } \\
\text { dari bawahannya } \\
\text { dan memecahkan } \\
\text { masalah secara } \\
\text { bersama dengan } \\
\text { bawahannya }\end{array}$ & $3 \%$ & $7,6 \%$ & $13,6 \%$ & $43,9 \%$ & $31,8 \%$ & $100 \%$ \\
\hline
\end{tabular}

Tabel 1.Distribusi Jawaban Responden Variabel Gaya Kepemimpinan 
P-ISSN 2580 - 7781

E-ISSN 2615 - 3238

Berdasarkan tabel 1 diketahui bahwa jawaban pernyataan sangat puas yang paling mendominasi terdapat pada indikator memecahkan masalah secara bersama serta memberikan kepercayaan tinggi terhadap bawahan dengan tidak melepaskan tanggung jawab pengawasan dengan pernyataan "Pimpinan senang menerima saran dari bawahannya dan memecahkan masalah secara bersama dengan bawahannya" sebesar 31,8\%.

b. Lingkungan Kerja

Pada variabel lingkungan kerja terdapat 4 pernyataan yang mempersentasikan indikator-indikator yang terkait dengan variabel lingkungan kerja, berikut jawaban yang diberikan oleh responden :

Tabel 2. Distribusi Jawaban Responden Variabel Lingkungan Kerja

\begin{tabular}{|c|c|c|c|c|c|c|c|}
\hline No & Pernyataan & STP & TP & $\mathbf{N}$ & $\mathbf{P}$ & SP & Skor \\
\hline 1 & $\begin{array}{l}\text { Kondisi udara di } \\
\text { ruang kerja (baik } \\
\text { dari ventilasi } \\
\text { udara, tanaman } \\
\text { yang ada disekitar } \\
\text { tempat kerja, air } \\
\text { condition (AC), } \\
\text { pewangi ruangan } \\
\text { memberikan } \\
\text { kenyamanan dalam } \\
\text { bekerja karena } \\
\text { membantu } \\
\text { menghilangkan } \\
\text { bau-bauan yang } \\
\text { mengganggu di } \\
\text { lingkungan kerja. }\end{array}$ & $1,5 \%$ & $0 \%$ & $4,5 \%$ & $59,1 \%$ & $34,8 \%$ & $100 \%$ \\
\hline 2 & $\begin{array}{l}\text { Adanya petugas } \\
\text { keamanan di } \\
\text { lingkungan tempat } \\
\text { kerja membuat } \\
\text { saya tenang dalam } \\
\text { bekerja }\end{array}$ & $1,5 \%$ & $0 \%$ & $10,6 \%$ & $51,5 \%$ & $36,4 \%$ & $100 \%$ \\
\hline 3 & $\begin{array}{l}\text { Penerapan struktur } \\
\text { kerja di instansi ini } \\
\text { berjalan sistematis } \\
\text { dan proporsional }\end{array}$ & $4,5 \%$ & $9,1 \%$ & $19,7 \%$ & $47 \%$ & $19,7 \%$ & $100 \%$ \\
\hline 4 & $\begin{array}{l}\text { Dalam instansi ini } \\
\text { sangat } \\
\text { mengedepankan }\end{array}$ & $1,5 \%$ & $10,6 \%$ & $18,2 \%$ & $47 \%$ & $22,7 \%$ & $100 \%$ \\
\hline
\end{tabular}


P-ISSN 2580 - 7781

E-ISSN 2615 - 3238

\begin{tabular}{l} 
kerjasama tim \\
(kelompok) serta \\
menjalin \\
komunikasi dengan \\
baik dan saling \\
terbuka \\
(transparan) antara \\
pegawai satu \\
dengan pegawai \\
lainnya ataupun \\
antara pegawai dan \\
pimpinan \\
\hline
\end{tabular}

Berdasarkan tabel 2 diatas diketahui bahwa jawaban pernyataan sangat puas yang paling mendominasi terdapat pada indikator faktor keamanan perlu diwujudkan keberadaannya sebagai salah satu upaya untuk menjaga keamanan di tempat kerja dengan pernyataan "Adanya petugas keamanan di lingkungan tempat kerja membuat saya tenang dalam bekerja" sebesar 36,4\%.

\section{Respon Pegawai Terhadap Gaya Kepemimpinan}

Deskripsi selanjutnya untuk mengetahui persentase pencapaian dan kategori per indikator respon pegawai terhadap gaya kepemimpinan Unars, langkahnya yaitu dengan mengetahui nilai persentase tiap indikator dengan rumus index $\%$. Hasil perhitungan persentase pencapaian dan kategori per indikator untuk variabel Gaya Kepemimpinan adalah sebagai berikut :

Tabel 3. Nilai Interpretasi Variabel Gaya Kepemimpinan

\begin{tabular}{lccl}
\hline \multicolumn{1}{c}{ Indikator } & $\begin{array}{c}\text { Total } \\
\text { Skor }\end{array}$ & $\begin{array}{c}\text { Hasil Index } \\
(\boldsymbol{\%})\end{array}$ & Kategori \\
\hline $\begin{array}{l}\text { Pimpinan mengatur sesuai keinginan } \\
\text { sendiri }\end{array}$ & 165 & 50 & $\begin{array}{l}\text { Cukup } \\
\text { Puas }\end{array}$ \\
\hline $\begin{array}{l}\text { Pimpinan tidak mau menerima saran } \\
\text { dan menetukan kebijakan sendiri }\end{array}$ & 143 & 43.33 & $\begin{array}{l}\text { Cukup } \\
\text { Puas }\end{array}$ \\
\hline $\begin{array}{l}\text { Pimpinan melibatkan partisipasi } \\
\text { bawahan }\end{array}$ & 261 & 79.09 & Puas \\
\hline $\begin{array}{l}\text { Pimpinan lebih memperhatikan kerja } \\
\text { kelompok dan komunikasi dua arah }\end{array}$ & 253 & 76.66 & Puas \\
\hline Pimpinan senang menerima saran & 260 & 78.78 & Puas \\
\hline \multicolumn{1}{c}{ Jumlah } & 1082 & 65.57 & Puas \\
\hline
\end{tabular}


P-ISSN $2580-7781$

E-ISSN 2615 - 3238

Berdasarkan tabel 3 diatas diperoleh data bahwa pegawai Universitas Abdurachman Saleh Situbondo mengaku puas dengan gaya pimpinan yang telah mereka hadapi saat ini. Hal tersebut terlihat dari 65,57\% nilai interpretasi masuk pada kategori puas. Penelitian ini menunjukkan bahwa responden melihat suatu gaya kepemimpinan dari pimpinan yang baik akan mampu mendukung dalam dia melaksanakan pekerjaannya. Hal ini selaras dengan penelitian yang dilakukan oleh Julianingtyas (2012) sehingga dapat dikatakan adanya hubungan antar gaya kepemimpinan bahwa pegawai yang dipimpin oleh seorang pimpinan yang memiliki cara memimpin yang baik dan disukai oleh bawahannya maka dia akan merasa senang dalam bekerja sehingga kinerjanya akan meningkat. Menurut Junaidi 7 Susanti (2019) keadaan ini dikarenakan pegawai dapat memberdayakan gaya kepemimpinannya. baik internal maupun eksternal, sehingga tercipta kondisi kerja yang kompetitif dan berupaya untuk selalu mampu menghadapi permasalahan yang dihadapi dalam menyelesaikan pekerjaanya menjadi lebih baik, dalam mewujudkan kualitas, kuantitas, ketepatan dan kemandirian kinerjanya.

Terdapat 2 indikator yang nilainya rendah yaitu pada pernyataan pimpinan mengatur sesuai keinginan sendiri mendapat nilai 50\% dengan kategori cukup puas. Hal ini menandakan bahwa separuh dari pegawai Unars menilai pimpinan tidak mengatur sesuai dengan keinginan sendiri. Pimpinan di Unars juga mau menerima saran dalam menentukan kebijakan, hal tersebut terlihat hanya sebagian kecil saja yaitu 43,33\% responden mengatakan cukup puas terhadap gaya pimpinan yang tidak mau menerima saran dan menetukan kebijakan sendiri.

Gaya kepemimpinan di Unars termasuk pada gaya kepempinan partisipatif, hal teresbut terlihat dari penilaian responden tertinggi adalah pimpinan melibatkan partisipasi bawahan dengan index 79,09\%. Kepemimpinan dengan menggunakan gaya atau model partisipatif yaitu seorang pemimpin dan pengikut atau bawahannya saling tukar menukar ide dalam pemecahan masalah dan pembuatan keputusan (Thoha, 2012). Menurut Sugino dkk (2017) kepemimpinan dan model kepemimpinan partisipatif di atas dapat ditarik kesimpulan bahwa kepemimpinan partisipatif adalah pemimpin yang lebih menekankan pada kerja kelompok sampai 
P-ISSN $2580-7781$

E-ISSN 2615 - 3238

di tingkat bawah, yaitu pemimpin yang menunjukkan keterbukaan dan memberikan kepercayaan yang tinggi pada bawahan.

\section{Respon Pegawai terhadap Lingkungan Kerja}

Lingkungan kerja yang nyaman akan memberikan dampak yang positif pada produktifitas pegawai. Tentu saja ini akan menjadi hal yang harus diperhatikan oleh instansi karena pegawai yang betah untuk mengerjakan tugasnya akan mampu mencapai tujuan organisasi. Tabel 4 berikut ini menujukkan respon pegawai Unars terhadap keadaan lingkungan kerja.

Tabel 4. Nilai Interpretasi Variabel Lingkunagan Kerja

\begin{tabular}{lccl}
\hline \multicolumn{1}{c}{ Indikator } & $\begin{array}{c}\text { Total } \\
\text { Skor }\end{array}$ & $\begin{array}{c}\text { Hasil } \\
\text { Index (\%) }\end{array}$ & Kategori \\
\hline Kondisi udara di ruang kerja & 281 & 85.15 & $\begin{array}{l}\text { Sangat } \\
\text { Puas }\end{array}$ \\
\hline $\begin{array}{l}\text { Lingkungan kerja karyawan tenang dan } \\
\text { bebas dari kebisingan suara lalu lalang } \\
\text { kendaraan }\end{array}$ & 159 & 48,18 & $\begin{array}{l}\text { Cukup } \\
\text { Puas }\end{array}$ \\
\hline $\begin{array}{l}\text { Petugas keamanan } \\
\text { Penerapan struktur kerja }\end{array}$ & 278 & 84.24 & $\begin{array}{l}\text { Sangat } \\
\text { Puas }\end{array}$ \\
\hline $\begin{array}{l}\text { instansi ini sangat mengedepankan } \\
\text { kerjasama tim (kelompok) serta menjalin } \\
\text { komunikasi dengan baik dan saling terbuka }\end{array}$ & 243 & 73.63 & Puas \\
\hline \multicolumn{1}{c}{ Jumlah } & & & \\
\hline
\end{tabular}

Berdasarkan tabel 4 diatas responden menyatakan sangat puas dengan nilai index $85.15 \%$ dengan kondisi ruang kerja yang nyaman baik dari ventilasi udara, tanaman yang ada disekitar tempat kerja, air condition (AC), pewangi ruangan memberikan kenyamanan dalam bekerja karena membantu menghilangkan baubauan yang mengganggu di lingkungan kerja. Hasil penelitian ini menunjukkan bahwa Unars telah memperhatikan pegawai dan interaksinya dengan lingkungan tempat kerja. Pegawai Unars merasa nyaman karena memang kondisi ruangan dibuat dengan fasilitas yang dibutuhkan oleh pegawai. Menurut Arjani (2011) hal tersebut dapat meningkatkan keselamatan, keamanan, kepuasan bekerja dan kualitas hidup serta mengurangi kelelahan dan stress manusia, dengan segala kemampuan dan keterbatasannya. 
P-ISSN 2580 - 7781

E-ISSN 2615 - 3238

Menurut Hendri (2012) Suatu kondisi lingkungan kerja dikatakan baik apabila dapat melaksanakan kegiatan secara optimal, sehat, nyaman dan aman. Lebih jauh lagi lingkungan kerja yang kurang baik dapat menyebabkan tidak efisiennya suatu rancangan sistem kerja, pola lingkungan kerja adalah pola tindakan anggota organisasi yang mempengaruhi efektivitas organisasi secara langsung atau tidak langsung, yang meliputi kinerja dan produktivitas, absenteisme dan perputaran, serta keanggotaan organisasi.

\section{KESIMPULAN}

Respon pegawai Unars terhadap gaya kepemimpinan adalah $65,57 \%$ puas dengan keadaan yang mereka rasakan saat penelitian ini dilakukan. Dengan gaya kepemimpinan partisipatif, pegawai senang dilibatkannya dalam pengambilan keputusan dengan adanya keterbukaan dan kepercayaan pimpinan kepada mereka. Selain itu responden $73,39 \%$ puas dengan lingkungan kerja yang dirasakan karena kondisi di ruang kerja nyaman sesuai dengan yang mereka butuhkan.

\section{DAFTAR PUSTAKA}

Arjani, I. A. M. S. (2011). Kualitas Udara dalam Ruang Kerja. Jurnal Skala Husada, 8(2).

Griffin. 2004. Manajemen, alih bahasa Gina Gania. Jakarta: Erlangga

Henri, E. (2012). Pengaruh lingkungan kerja fisik dan non fisik terhadap kepuasan kerja karyawan pada pt asuransi wahana tata cabang palembang. Jurnal Media Wahana Ekonomika, 9(3), 1-16.

Julianigtyas, B. N. (2012). Pengaruh Locus Of Control, Gaya Kepemimpinan Dan Komitmen Organisasi Terhadap Kinerja Auditor. Accounting Analysis Journal, 1(1).

Junaidi, R., \& Susanti, F. (2019). Pengaruh Gaya Kepemimpinan Dan Budaya Organisasi Terhadap Kinerja Pegawai Pada UPTD Baltekkomdik Dinas Pendidikan Provinsi Sumatera Barat.

Nawawi, 2006. Kepemimpinan Mengefektifkan Organisasi. Yogjakarta: Toko Gunung Agung.

Sedarmayanti. 2009. Sumber daya Manusia dan Produktivitas Kerja. Bandung: CV. Mandar Maju

Sugino, S., Miyono, N., \& Retnaningdyastuti, R. (2017). GAYA KEPEMIMPINAN PARTISIPATIF DAN FUNGSI KEPEMIMPINAN SANGGAR BUDAYA SATRIA WONOSOBO. Jurnal Manajemen Pendidikan (JMP), 6(1). 
P-ISSN 2580 - 7781

E-ISSN 2615 - 3238

Thoha, Miftah. 2012. Kepemimpinan Dalam Manajemen. Ed. 1. Jakarta: Rajawali Press

Windura, B., Satriawan, R. A., \& Silalahi, S. P. (2017). Pengaruh Gaya Kepemimpinan, Profesionalisme, Lingkungan Kerja dan Kecerdasan Emosional terhadap Kinerja Pengelola Keuangan (Studi pada Skpd Kota Dumai) (Doctoral dissertation, Riau University). 